\title{
Development of in vitro propagation system for Atriplex halimus $\mathbf{L}$.
}

\author{
Aldahhak, O. ${ }^{1}$; Zaid, S. ${ }^{1}$ \& Abdul-Kader, A.M. ${ }^{2}$ \\ ${ }^{1}$ Biology Department, Faculty of Science, Damascus University, Damascus, P.O. Box 35158, Syria. \\ ${ }^{2}$ General Commission for Scientific Agricultural Research (GCSAR), Biotechnology Department, P.O. Box 12573, \\ Damascus, Syria. Fax: 00963-11-2254884; \\ e-mail: ahmadabdulkader2@gmail.com ${ }^{1}$
}

\begin{abstract}
Summary: Explants excised from adult shrubs were surface sterilized and cultured on Murashige and Skoog (MS) basal medium in the presence of plant growth regulators (PGRs) at different concentrations. A high multiplication rate of 7.2-fold was achieved every four weeks on MS medium supplemented with $4.44 \mu \mathrm{M}$ BA, $0.49 \mu \mathrm{M}$ IBA and $0.58 \mu \mathrm{M} \mathrm{GA}_{3}$. Rooting was achieved with $73 \%$ efficiency within $2-4$ weeks on agar-gelled MS basal medium free of PGRs. Rooted plantlets were gradually acclimatized to field conditions over 5-6 weeks with $65 \%$ efficiency. For in vitro selection for salt tolerance, MS medium was supplemented with increasing concentrations of $\mathrm{NaCl}$ ranging between 25 and $1000 \mathrm{mM}$. This study has demonstrated that in vitro shoots could tolerate up to $600 \mathrm{mM} \mathrm{NaCl}$ with optimal growth at $200 \mathrm{mM}$, while higher concentrations of $\mathrm{NaCl}$ affected growth negatively. Growth and shoot number decreased with increasing $\mathrm{NaCl}$ concentration with all plantlets died at $1000 \mathrm{mM} \mathrm{NaCl}$.
\end{abstract}

Keywords: cytokinin, in vitro regeneration, shoot formation, Salt tolerance in vitro

Abbreviations: 2,4-D, 2,4-dichlorophenoxy acetic acid; 2iP, isopentenyl- adenine; BA, N $\mathrm{N}^{6}$-benzyladenine; GA , gibberellic acid; ha, hectare; IAA, indole-3-acetic acid; IBA, indole-3-butyric acid; MS, Murashige and Skoog; NAA, -naphthalene acetic acid; NN, Nitsch and Nitsch; PGR, plant growth regulator; WPM, medium, McCown Woody Plant Medium (1980)

\section{Introduction}

Syrian Arab Republic is located on the Eastern coast of the Mediterranean Sea with an area of 18.517.071 ha and a population of about 20.376 million (Anon 2009). Dry land in Syria accounts for about 10 million ha, about 55\% of the entire country, with annual rainfall of $<200 \mathrm{~mm}$ per year for the last 20 years (Wardeh 2005). Desertification is threatening large areas in Syria mainly due to salinity, which has expanded to the irrigated areas in the Eastern part of the country (Harba 2006). Therefore, it is crucial to prevent salinity and desertification in any way possible. One way to rehabilitate and reclaim these soils is by planting salt-tolerant forage species. Among these species is the genus Atriplex, which has recently raised interest where some 100.000 ha have been planted in the Mediterranean basin, Species of the genus Atriplex are known for their high tolerance to aridity and salinity (Le Houerou 1992). Using halophytes to produce forage in saline lands is the best economic solution (Khan and Duke 2001). Halophytes can play a role in soil reclamation in degraded lands (Le Houerou 1992). Atriplex are the dominant plants in arid and semi-arid lands of the world, especially when soil is combined with salinity (Ortíz et al. 2005). Atriplex halimus L. is a member of the Chenopodiaceae and one of the major species used in combating desertification due to its salt tolerance, which is defined as a plant's ability to grow under saline stress (Munns 2002). A. halimus is an important Mediterranean xerohalophyte salt bush species highly resistant to drought (Le Houerou 2000), salinity (Bajji et al. 1998) and heavy metal stress (Lutts et al. 2004). Therefore, this study was carried out to develp an efficient micropropagation system for large-scale rapid clonal multiplication and spreading its cultivation to contribute in alleviating desertification impact on the environment and Humans. Another objective was the selection of in vitro of highly salt-tolerant clones by increasing concentrations of $\mathrm{NaCl}$ on in vitro grown plantlets.

\section{Materials and methods}

Plant material and media. Plant material used in this study was obtained from a shrub of A. halimus grown in a desert area at Altalila Reservation near Palmyra, Syria. 
Half-strength Murashige and Skoog (MS, 1962) was used as basal medium for shoot initiation, used throughout this research, supplemented with $3 \%$ sucrose (HiMedialaboratories Pvt. Limited, India) and solidified with 0.7\%agar (HiMedia -laboratories Pvt. Limited, India). And for multiplication medium six combinations of hormonal were added to the basic medium (Table 1). Three explants were cultured in each glass jar $(200 \mathrm{ml})$ containing $30 \mathrm{ml}$ medium. For rooting medium MS basal medium free of PGRs (as control), 3\% sucrose and solidified with $0.7 \%$ agar or supplemented with IBA at 0.49 or $2.45 \mu \mathrm{M}$. were used. and for salt tolerance MS basal medium was supplemented with increasing concentrations of $\mathrm{NaCl}(25,50,100,150$, $200,300,400,500,600,1000 \mathrm{mM}$ ) to study the effect of salt on multiplication and selection in vitro of shoots which tolerate high concentrations of salt.

Culture conditions. The shoot cultures were maintained in a growth room at $25 \pm 1{ }^{\circ} \mathrm{C}$ and a 16-h photo period provided by Philips fluorescent lamps giving an average light intensity of $c a .50 \mu \mathrm{mol} \mathrm{m} \mathrm{m}^{-2} \mathrm{~s}^{-1}$ photon flux at the surface of culture vessels to assess shoot induction responses. All media were adjusted to $\mathrm{pH} 5.7$ with $1 \mathrm{~N} \mathrm{KOH}$ or $1 \mathrm{~N} \mathrm{HCl}$ prior to autoclaving at $121^{\circ} \mathrm{C}, 1.4 \mathrm{~kg} / \mathrm{cm}^{2}$ for $20 \mathrm{~min}$.

Acclimatization. Rooted plantlets were then acclimatized gradually to field conditions by transplanting into pots with a mixture of 2: $1(\mathrm{v} / \mathrm{v})$ peatmoss : perlite (local origin Mahran, Syria) and were covered with plastic bags and acclimatized gradually to field conditions for a 4-week period.

Experimental design and statistical analysis. Data of all experiments were recorded after 4 weeks from culture on the experimental media. Thirty replicates were used per proliferation treatment and 20 replicates per rooting treatment. Each culture jar was a repetition in a randomized block experimental design, in which the six different media were compared. For each treatment, 30 explants were used with 3explants/jar and 10 replications. Significance was determined at $P=0.05$ according to Duncan's multiple range test by analysis of variance (ANOVA-2) using the statistical evaluation program SPSS v. 15 .All experiments were repeated three times.

\section{Results and discussion}

Disinfection and culture initiation. In vitro contamination is a serious problem with tissue culture initiation. Commercial Clorox (5.25\%sodium hypochlorite) efficiently surface-disinfected explants. immersion in $15 \%$ commercial Clorox for $25 \mathrm{~min}$ was the best method for surface disinfection with $79 \%$ efficiency decontamination of which $92 \%$ were survived (Fig. 1). Higher concentrations were too strong, caused bleaching with resulting death of explants. Kenny and Caligari (1996) used 5\%commercial Cloroxto surface sterilize A. glauca flower clusters. In our study, in contrast, we used $15 \%$ Clorox because A.halimus is a woody plant, unlike A.glauca. In addition, we used axillary buds which are harder than flowers. Mei et al. (1997) used
$100 \%$ commercial bleach for $20 \mathrm{~min}$ to sterilize Axillary buds and leaf disc of A.canescens.

Effects of PGRs on shoot organogenesis and shoot multiplication in vitro A. halimus

Adventitious shoots originating along the cut base of explants and were clearly visible after 3-4 weeks' culture, best shoot multiplication was achieved on media supplemented with $4.44 \mu \mathrm{M}$ BA, $0.49 \mu \mathrm{M}$ IBA and $0.58 \mathrm{GA}_{3}$ with a multiplication rate of 7.2 shoots/ explants (Table 1, Fig. 2) . There was a significant reduction in shoot multiplication rate when BA was replaced with Kin., which resulted in a multiplication rate of 2.1 .

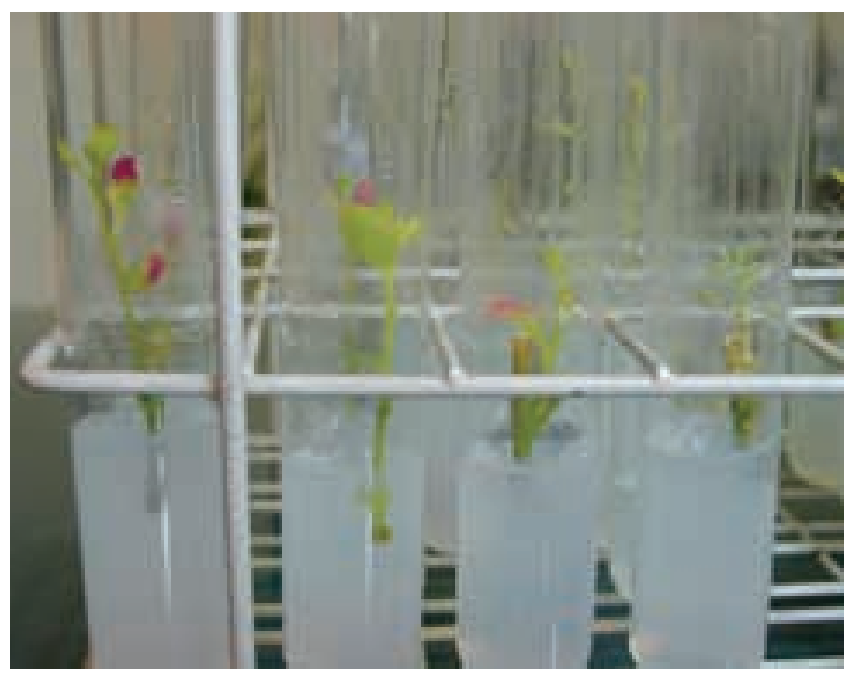

Fig. 1: Initial culture of Atriplex halimus L.

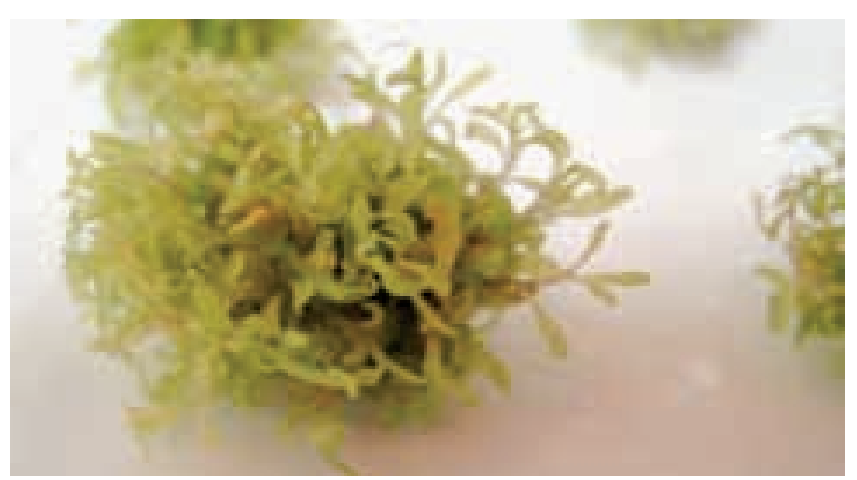

Fig. 2: Effect of best combination of growth regulators on in vitro proliferation of Atriplex halimus L.

Results presented in Table 1 demonstrate the effects of a combination of PGRs at different concentrations on the number and length of shoots. The best multiplication rate was achieved on medium containing $4.44 \mu \mathrm{M} \mathrm{BA}+0.49 \mu \mathrm{M}$ IBA $+0.58 \mu \mathrm{M} \mathrm{GA}_{3}$ with an average of 7.26 new shoots/explant every 4 weeks (Fig.2). On other hand, control medium gave the best average shoot length $(2.08 \mathrm{~cm})$ (Fig.3).

The results presented here confirm earlier observations of Malan (2000) who reported that the best medium for shoot multiplication and elongation of A.canescens was MS with $0.20 \mathrm{mg} / \mathrm{l} \mathrm{BA}+1 \mathrm{mg} / \mathrm{l} \mathrm{NAA}$ while MS medium with $0.05 \mathrm{mg} / \mathrm{l}$ 
$\mathrm{BA}+0.05 \mathrm{mg} / \mathrm{l}$ NAA was best for elongation. Our results also agree with those of Mei et al.(1997) who produced shoots from both leaf discs and axillary buds. In their study, the best medium for shoot production was $2 \mathrm{mg} / \mathrm{l} \mathrm{BA}$ and $0.01 \mathrm{mg} / \mathrm{l}$ NAA while the best medium for shoot elongation was PGRfree MS: the number of shoots generated ranged from 0.7 to 9.1/ explant. Reddy et al. (1996) found that MS medium with $0.5 \mathrm{mg} / \mathrm{l} \mathrm{BA}$ or $0.5 \mathrm{mg} / \mathrm{l} \mathrm{Kin}$ was best for micropropagation of $A$. nummularia.

Table 1 Effect of PGRs combinations on number and length of shoots produced in vitro in A. halimus L. within 4 weeks of culture

\begin{tabular}{|c|c|c|c|}
\hline $\begin{array}{l}\text { Treat- } \\
\text { ment }\end{array}$ & $\begin{array}{c}\text { Combination of } \\
\text { PGRs } \\
\text { (Conc. in } \mu \mathrm{M})\end{array}$ & $\begin{array}{l}\text { Average of shoot } \\
\text { number }( \pm \mathrm{SE}) *\end{array}$ & $\begin{array}{c}\text { Average of shoot } \\
\text { length }(\mathrm{cm}) \\
\text { SE)* }\end{array}$ \\
\hline 1 & $\begin{array}{l}\mathrm{MS}+2.22 \mathrm{BA}+ \\
0.49 \mathrm{IBA}+0.58 \\
\mathrm{GA} 3\end{array}$ & $4.73 \pm 0.15 b$ & $1.05 \pm 1.25 b$ \\
\hline 2 & $\begin{array}{l}\mathrm{MS}+4.44 \mathrm{BA}+ \\
0.49 \mathrm{IBA}+0.58 \\
\mathrm{GA} 3\end{array}$ & $7.26 \pm 0.32 \mathrm{a}$ & $1.0 \pm 2.05 \mathrm{~b}$ \\
\hline 3 & $\begin{array}{l}\mathrm{MS}+2.22 \mathrm{Kin}+ \\
0.49 \mathrm{IBA}+0.58 \\
\text { GA3 }\end{array}$ & $2.96 \pm 0.16 b c$ & $1.07 \pm 0.61 b$ \\
\hline 4 & $\begin{array}{l}\mathrm{MS}+4.44 \mathrm{Kin}+ \\
0.49 \mathrm{IBA}+0.58 \\
\text { GA3 }\end{array}$ & $2.13 \pm 0.27 \mathrm{c}$ & $1.06 \pm 0.28 b$ \\
\hline 5 & $\begin{array}{l}\mathrm{MS}+0.49 \mathrm{IBA}+ \\
0.58 \mathrm{GA} 3\end{array}$ & $2.36 \pm 0.32 c$ & $1.16 \pm 0.55 b$ \\
\hline 6 & $\begin{array}{l}\text { MS medium } \\
\text { Control (Free of } \\
\text { PGRs) }\end{array}$ & $4.4 \pm 0.89 b c$ & $2.08 \pm 1.22 \mathrm{a}$ \\
\hline & LSD 0.05 & 2.53 & 0.59 \\
\hline
\end{tabular}

Different letters within a column indicate significant differences according to Duncan's multiple range test $(\mathrm{P}<0.05)$.

Data are means of 30 replications

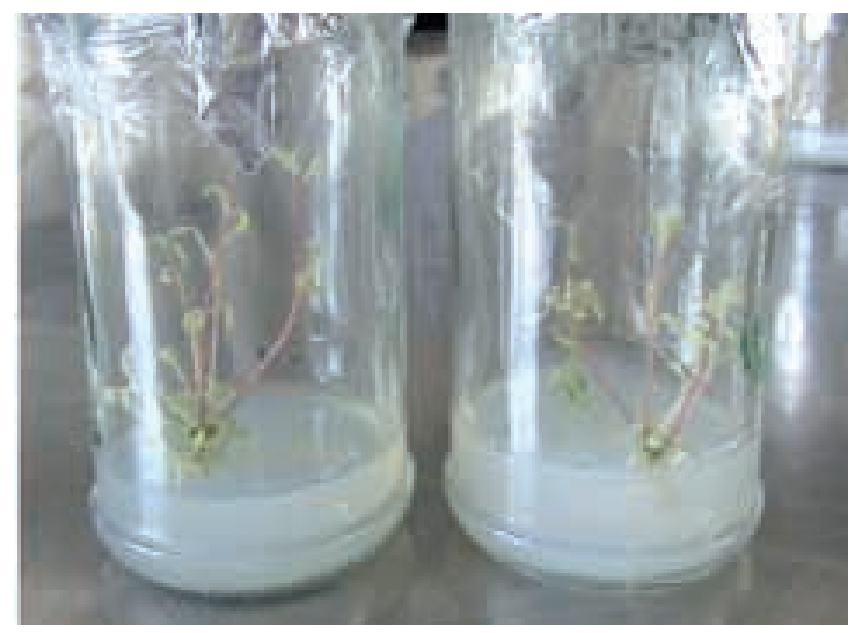

Fig. 3. In vitro elongation of Atriplex halimus $\mathrm{L}$ on control medium

Cytokinins such as TDZ and BAP have considerable effects in inducing regeneration in most woody plants (Korban et al.1992; De Bondt et al. 1996). BA has been the most commonly used cytokinin for proliferation of many plants (Murai et al. 1997). A high concentration of cytokinin with low concentrations of auxins results in a high proliferation efficiency in many plant species (Pierik 1987).

In the present study, however, although induction of shoots was observed in most media tested, BA proved to be more efficient than Kin in shoot induction (Table 1).

Our results demonstrate that an optimum combination of PGRs plays a key role in the successful induction of shoot organogenesis in vitro. The number of shoots/explant was influenced by the type and concentrations of PGRs used. The number of newly produced shoots varied between 2.1 and 7.2 (Table 1). No abnormality, necrosis or chlorosis was observed during culture. Most explants produced shoots and green shoot meristems were seen on a range of media containing BA or Kin and also on control medium free of PGRs.

Multiple shoot induction rate and organogenic response varied significantly to a greater extent according to the explant type and concentrations of PGRs used. Kenny and Caligari (1996) recorded that NN medium was more appropriate than MS medium in their study on A.glauca, The IAA/2iP combination at $0.1 / 0.1 \mathrm{mg} / \mathrm{l}$ was better than IAA/Kin at $0.1 / 0.1 \mathrm{mg} / \mathrm{l}$ and gave the best response with this species. Zohra et al.(2008) found that MS medium with Kin. and $2 \mathrm{mg} / \mathrm{l}$ 2,4-D was best for in vitro shoot induction from the calli of A.halimus and A.canescens. However, our study showed that shoots could be induced in only 4weeks unlike the study of Mei et al.(1997) who noted that shoot induction in A.canescens took at least 2 months. In our study, however, shoot formation could be developed without an intervening callus phase. Moreover, the type of explant and culture medium with specific PGR concentrations influenced organogenesis considerably. We demonstrated that shoot tips and nodal explants can be used for clonal propagation on optimum culture medium.

In vitro Rooting. Proliferated shoot tips (2-3 cm length) were excised and rooted readily on MS medium. Rooting was observed from the cut ends of the shoots within 30 days. All of the developing roots were physically vigorous and healthy. Results in Table 2 present rooting data: best rooting rate $(73.33 \%)$ with average number of roots $=3.3$ and best average of stem length of $1.63 \mathrm{~cm}$ were achieved on MS medium (Fig. 4) while $46 \%$ rooting efficiency could be recorded onmedium containing $0.49 \mu \mathrm{M}$ IBA. Our study agrees with the findings of Malan (2000) who noted that MS basal medium without any PGRs was the best medium for rooting. Al-Wasel (1998), who studied the micropropagation of A. nummularia, noted that $1 / 2-\mathrm{MS}$ without PGRs with phloroglucinol (162 mg/l) was the best rooting media. In contrast, Mei et al.(1997) produced A.canescens roots using $0.5 \mathrm{mg}$ IBA and $0.1 \mathrm{mg} / \mathrm{GA}_{3}$ in $\mathrm{MS}$ medium with $65 \%$ success. In several species, the utilization of high concentrations of IBA produces callus and abnormal roots that affect the survival of explants during acclimatization (Welander 1983; Yepes and Aldwinckle 1994). In the current study, high concentrations of auxins did not give good results and callus formation was induced at the bases of 
shoots. Best rooting percentage was better on medium free of PGRs or containing low concentration of auxin (Table 2, Fig. 4). Amato et al.(1990) recorded best rooting percentage of $67 \%$ using IBA at $2000 \mathrm{mg} / \mathrm{l}$ although increasing IBA concentration to $4000 \mathrm{mg} / \mathrm{l}$ resulted in decreased rooting to $40 \%$. However, in our study, $73 \%$ rooting efficiency could be obtained on media without any auxin while use of IBA at 0.49 and $2.45 \mu \mathrm{M}$ (equiv. 0.1 and $0.5 \mathrm{mg} / \mathrm{l}$ ) decreased rooting efficiency to 46.6 and $20 \%$, respectively.

Shoot tips and axillary buds from 2-year-old shrubs were excised and used for micropropagation because some studies mentioned that shoot age influences rooting positively probably because of the greater quantity of reserve material, or because of bud dormancy (Amato et al. 1990).

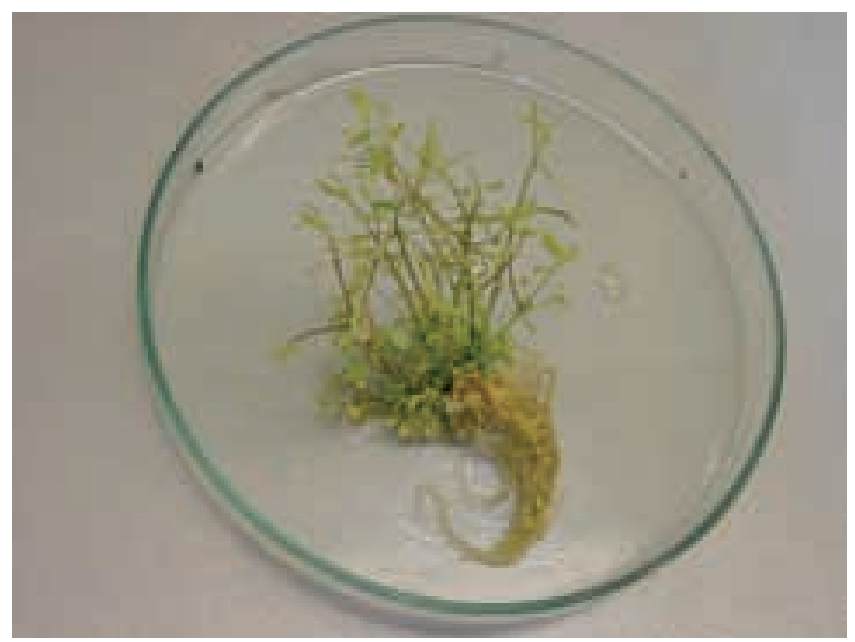

Fig. 4. Rooting in vitro of Atriplex halimus

Table 2. Effect of IBA concentration on rooting parameters in vitro in A. halimus L. within 4 weeks of culture on rooting media

\begin{tabular}{|c|l|l|l|l|}
\hline $\begin{array}{c}\text { Treat- } \\
\text { ment }\end{array}$ & $\begin{array}{l}\text { Concentration } \\
\text { of IBA }(\mu \mathrm{M})\end{array}$ & $\begin{array}{c}\text { Rooting\% } \\
( \pm \text { SEM })^{*}\end{array}$ & $\begin{array}{c}\text { Average of } \\
\text { root number } \\
( \pm \mathrm{SE})^{*}\end{array}$ & $\begin{array}{c}\text { Average of } \\
\text { root length } \\
(\mathrm{cm})( \pm \mathrm{SE})^{*}\end{array}$ \\
\hline 1 & 0.49 & $\begin{array}{l}46.67 \pm \\
0.15 \mathrm{~b}\end{array}$ & $1.93 \pm 0.60 \mathrm{a}$ & $1.14 \pm 0.09 \mathrm{a}$ \\
\hline 2 & 2.45 & $20 \pm 0.1 \mathrm{c}$ & $2.33 \pm 0.57 \mathrm{a}$ & $0.64 \pm 0.16 \mathrm{~b}$ \\
\hline 3 & $\begin{array}{l}\text { Control (free } \\
\text { of PGRs })\end{array}$ & $\begin{array}{l}73.33 \pm \\
0.251 \mathrm{a}\end{array}$ & $3.33 \pm 1.02 \mathrm{a}$ & $1.63 \pm 0.87 \mathrm{a}$ \\
\hline \multicolumn{2}{|c|}{ LSD 0.05 } & 12.56 & 1.4 & 0.49 \\
\hline
\end{tabular}

Different letters within a column indicate significant differences according to Duncan's multiple range test $(P<0.05)$.

Data are means of 20 replications

\section{Acclimatization of rooted plantlets}

During in vitro culture, plantlets grow under very special conditions, these conditions result in the formation of plantlets of abnormal morphology, anatomy and physiology. After transfer from the in vitro to the ex vitro conditions, the plantlets have to correct the abovementioned abnormalities. However, plantlets need gradual changes in environmental conditions to avoid desiccation losses and photo inhibition (Kozai et al.1991).Al-Wasel (1998) reported a 55\%acclimatization efficiency form icropropagated $A$. nummularia, which is in agreement with the findings of our study but $65 \%$ efficiency for A. halimus in which rooted plantlets were acclimatized to ambient conditions within 2 months and were later established under greenhouse conditions (Fig. 5) and finally in the field under natural conditions (Fig. 6). Mei et al. (1997) also reported $65 \%$ survival of acclimatized shoots of A.canescens. Rooted A.canescens plantlets were also successfully acclimatized by Malan (2000) but without any reference to the acclimatization efficiency obtained.

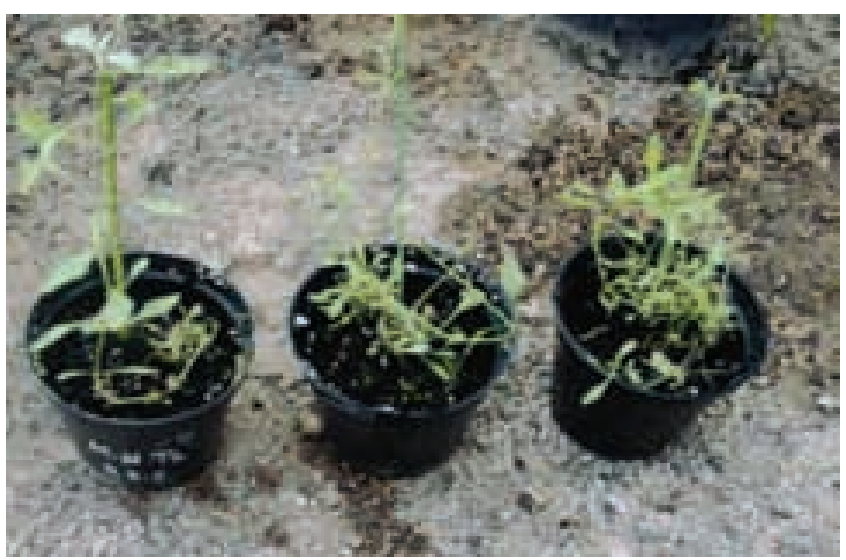

Fig. 5. In vitro propagated acclimatized Atriplex halimus (2-3 months old) grown in the green house

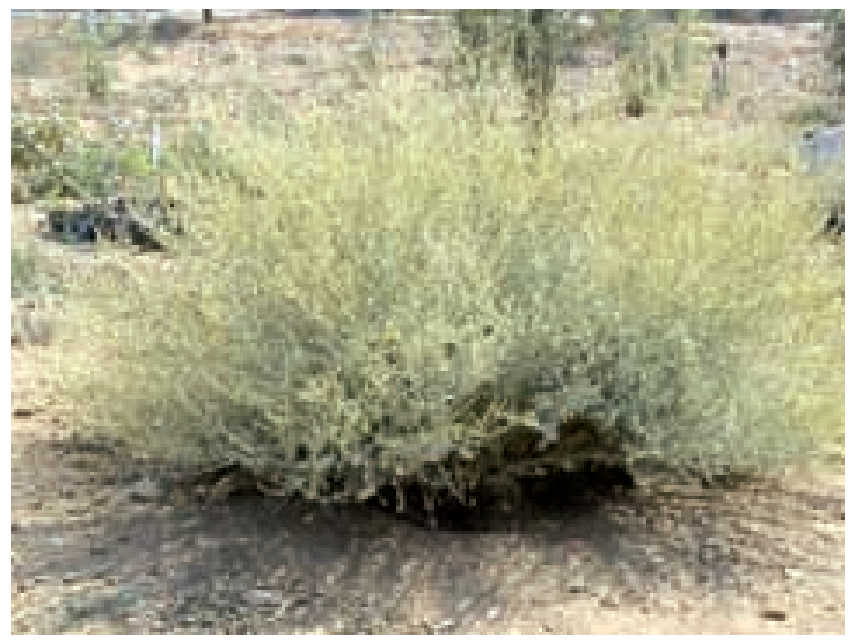

Fig. 6. In vitro propagated Atriplex halimus (1 year old) under field condition

\section{In vitro selection for salt tolerance in A. Halimus}

Results of the present study indicate that A. halimus is a salt-tolerant species also in vitro conditions, where an increase in shoot number could be recorded in media containing up to $200 \mathrm{mM} \mathrm{NaCl}$, while higher concentrations of $\mathrm{NaCl}$ (400-500-600 mM) inhibited plant growth in vitro 
(Table 3). This result is in agreement with Khan et al.(2000) who recorded little inhibition in seedling growth of $A$. griffithi in media containing up to $180 \mathrm{mM} \mathrm{NaCl}$, while 360 $\mathrm{mM} \mathrm{NaCl}$ inhibited plant growth.

Table 3. Effect of $\mathrm{NaCl}$ concentrations on the number and length of shoots produced in vitro in A. halimus L. within 4 weeks of culture

\begin{tabular}{|c|c|c|c|}
\hline $\begin{array}{c}\text { Medium } \\
\text { No. }\end{array}$ & $\begin{array}{c}\text { NaCl conc. } \\
(\mathbf{m M})\end{array}$ & $\begin{array}{c}\text { Mean Shoots Length } \\
(\mathbf{c m})( \pm \mathbf{S E})^{*}\end{array}$ & $\begin{array}{c}\text { Mean Shoots } \\
\text { No. }( \pm \text { SE) }\end{array}$ \\
\hline 1 & 25 & $3.22 \pm 0.56 \mathrm{a}$ & $2.76 \pm 1.1 \mathrm{abc}$ \\
\hline 2 & 50 & $2.17 \pm 0.31 \mathrm{bcd}$ & $2.6 \pm 1.7 \mathrm{abc}$ \\
\hline 3 & 100 & $2.76 \pm 0.42 \mathrm{ab}$ & $3.3 \pm 0.75 \mathrm{ab}$ \\
\hline 4 & 150 & $2.63 \pm 0.40 \mathrm{abc}$ & $2.53 \pm 0.2 \mathrm{abc}$ \\
\hline 5 & 200 & $1.99 \pm 0.19 \mathrm{~cd}$ & $3.73 \pm 1.01 \mathrm{a}$ \\
\hline 6 & 300 & $2.07 \pm 0.22 \mathrm{~d}$ & $2.33 \pm 0.15 \mathrm{abc}$ \\
\hline 7 & 400 & $1.94 \pm 0.22 \mathrm{~d}$ & $3.1 \pm 0.43 \mathrm{abc}$ \\
\hline 8 & 500 & $1.57 \pm 0.46 \mathrm{~d}$ & $1.53 \pm 0.37 \mathrm{bc}$ \\
\hline 9 & 600 & $1.83 \pm 0.16 \mathrm{~d}$ & $1.46 \pm 0.46 \mathrm{~d}$ \\
\hline LSD 0.05 & & 0.75 & 0.16 \\
\hline
\end{tabular}

Different letters within a column indicate significant differences according to Duncan's multiple range test $(P<0.05)$. Data are means of 30 replications

Our study indicated that $A$. halimus is a highly salt-tolerant species that survived at $600 \mathrm{mM} \mathrm{NaCl}$ (salinity of seawater). $\mathrm{NaCl}$ at $200 \mathrm{mM}$ was most conducive to plant growth, where the size of leaves was bigger than the control (Fig.7). $\mathrm{NaCl}$ has been used in most studies on salt tolerance in many plants. However, Nedjimi et al. (2006) used $\mathrm{CaCl}_{2}$ to study salt tolerance in A.halimus and found that $8 \mathrm{~g} \mathrm{l}^{-1} \mathrm{CaCl}_{2}$ (about 72 $\mathrm{mM}$ ) allowed best plant growth. Similar results were found on a study on A.nummularia which showed that the growth gain of plants was stimulated by $22 \%$ with $\mathrm{NaCl}$ at $300 \mathrm{mM}$, and then reduced significantly in the highest $\mathrm{NaCl}$ treatment of $600 \mathrm{mM} \mathrm{NaCl}$ with a $26 \%$ decrease in growth relative to the control. A.nummularia takes up $\mathrm{Na}^{+}$and $\mathrm{Cl}^{-}$in high amounts, but seems to store them efficiently up to an external $300 \mathrm{mM}$ $\mathrm{NaCl}$ level only. Above this concentration, however, such a mechanism fails and growth of shoot tissues is negatively affected (Araújo et al. 2006). Our results also similar to those of Greenway et al.(1966) who reported that growth of $A$. nummularia was optimal at 100 to $200 \mathrm{mM} \mathrm{NaCl}$. Our results also confirm the observations of Ashby and Beadle (1975) that showed that growth of A. inflata and A.nummularia was greater with $\mathrm{NaCl}$ at $600 \mathrm{mM}$ than in controls.

The growth of halophytes such as Atriplex spp. is stimulated by $\mathrm{NaCl}$ concentration which would inhibit the growth of non-halophytes (Osmond et al. 1980). It seems that growth response at moderate salinities might be largely the consequence of increased through put of solutes required to derive cell expansion (Khan et al. 2001). An important finding is that plants could survive at600 $\mathrm{mM} \mathrm{NaCl}$, which might be suitable concentration to use for selection of highly salt-tolerant plants. Higher stress with $\mathrm{NaCl}$ induced death in almost all shoots, while just a few could survive, which were selected and multiplied under the same stress conditions for further studies in the near future. Many studies have shown that Atriplex spp. such as A. nummularia, A. griffithii and A. hortensis could survive under highly saline conditions, with optimal growth occurring at 5 to $10 \mathrm{~g} \mathrm{l}^{-1} \mathrm{NaCl}(85.5-171 \mathrm{mM})$ (Khan et al.2000; Wilson et al. 2000; Ramos et al.2004) which are in agreement with Pribe and Jäger (1978) who found that Atriplex spp. vary in their degree of salt tolerance, but all three species studied (A. halimus, A.calotheca, A.nilens) were able to survive at $750 \mathrm{mM} \mathrm{NaCl}$. Storey and Wyn Jones (1979) determined that $A$. spongiosa was able to grow in medium containing $600 \mathrm{mM} \mathrm{NaCl}$ with dry mass production decreasing by $50 \%$ at $800 \mathrm{mM} \mathrm{NaCl}$. Our study indicates that increasing $\mathrm{NaCl}$ concentrations had a negative effect on plant growth; there are many studies indicating that $\mathrm{Na}^{+}$and $\mathrm{Cl}^{-}$ content in shoots and roots increased with increasing salinity (Greenway et al. 1966; Khan et al.2000;Nedjimiet al. 2006). Many of the deleterious effects of $\mathrm{Na}^{+}$seem to be related to structural and functional integrity of membranes (Kurth et al.1986). At high salinities, growth reduction might be caused by a reduced ability to make osmotic adjustment as a result of saturation of the solute uptake system (Munns2002). Expose to saline concentrations $(400-600 \mathrm{mM} \mathrm{NaCl}$ on Arthrochnemumm acrostachyum) has been shown to increase tissue water content of halophytes (Khan et al.2005). The water potential of $A$. halimus decreased as salinity levels increase(72-108 $\mathrm{mM} \mathrm{CaCl}_{2}$ ) (Nedjimi et al. 2006). Also, the water potential of $A$. griffithii became increasingly negative as media salinity increase (up to $360 \mathrm{mM} \mathrm{NaCl}$ ) (Khan et al.2000). Deleterious effects of salinity are thought to result from low water potentials, ion toxicities, nutrient deficiencies, or a combination of these factors (Munns2002). Growth and survival of halophytes is dependent on high levels of ion accumulation in their tissues for the maintenance of tugor and osmotic adjustment (Flowers et al.1977). Halophytes are distinguished by their capacity to produce high concentrations of combatable osmotics to tolerate salinity by increasing ion accumulation (Khan et al.2000). Salt tolerance in A. halimus could involve a delicate balance among ion accumulation, osmotic adjustment, and maintenance of pressure potential and growth. At relatively high salinities, a significant reduction in growth occurs because of a plant's inability to make an osmotic adjustment, and specific ion toxicities can cause a significant reduction in growth (Nedjimi et al.2006).

In the current study we noticed that the plantlet leaves under high $\mathrm{NaCl}$ concentration turned whitish in comparison to the control. This can be ascribed to the fact that the shoots of A.halimus expunged excess amounts of $\mathrm{NaCl}$ to the outer surfaces of leaves giving them this whitish color. Many Atriplex species including A. halimus have glands on the surface of leaves where salt crystallizes without being harmful (Taiz and Zeiger 1991). Although high amounts of $\mathrm{Na}^{+}$accumulate outside $A$. halimus leaves in vesiculated hairs (avoidance structure) (Araújo et al. 2006). this protective mechanism does not alone explain the stimulation of growth 

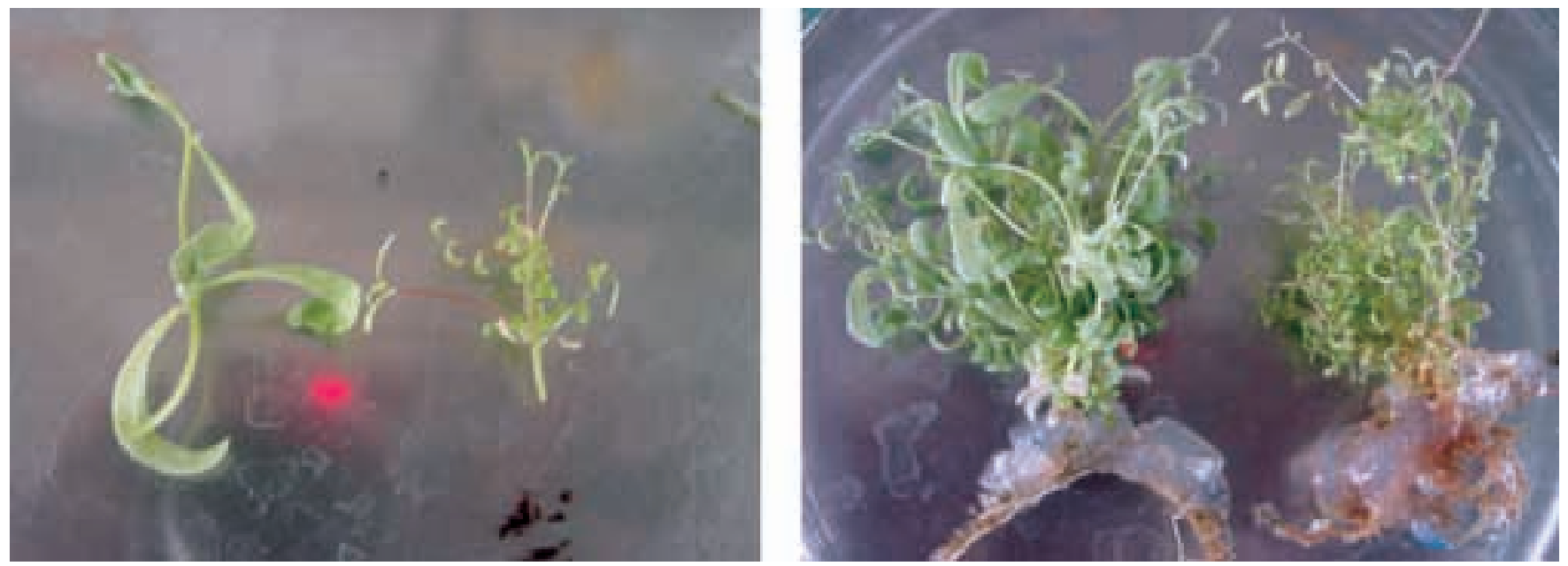

Fig. 7. Effect of $\mathrm{NaCl}$ on the growth and size of the leaves in vitro of A. halimus $\mathrm{L}$.

Left: shoots grown on medium 5 with $200 \mathrm{mM} \mathrm{NaCl}$. Right: Control: shoots grown on medium free of $\mathrm{NaCl}$

recorded in the present study. Such an assumption agrees with that of Bajji et al. (1998) who studied A. halimus grown in media artificially salinized with $\mathrm{NaCl}$. They reported that the physiological mechanism underlying growth stimulation of Atriplex plants is still unknown and that such a genus undoubtedly constitutes one of more convenient subjects for investigating the halophytic properties in the plant kingdom. Although not proven, an assumption exists where increased activity of protein synthesis leads to improved growth and is considered of great biochemical and physiological relevance within a given range of $\mathrm{NaCl}$ depending on the plant species(Araújo et al. 2006). A. nummularia may use the controlled uptake of $\mathrm{Na}^{+}$balanced by other ions, especially $\mathrm{Cl}^{-}$, into a cell to drive water into the plant against low external water potential (Blumwald et al. 2000). A. halimus adopted two different strategies: it behaved as a salt includer at low salinity and as an excluder at high salinity, and growth stimulated in the range of $\mathrm{NaCl}$ from 150 to $300 \mathrm{mM}$ (Bajji et al. 1998) which agrees with our present study in which optimal growth occurred at $200 \mathrm{mM}$.

Our study indicates that salinity affected rooting negatively; the higher the salinity, the fewer the roots, which is unlike what Araújo et al.(2006) found, i.e. that salinity did not affect rooting. Just a few clones which tolerated high concentrations of $\mathrm{NaCl}$ were selected and are being propagated under the same stress conditions for the next step of our study for identification and isolation of salt tolerance gene(s) from these high salt-tolerant clones selected in vitro under high stress concentration of $\mathrm{NaCl}$ to be used for transformation of crops for salt and drought stress tolerance.

\section{Conclusions}

An efficient system for clonal multiplication and shoot organogenesis was developed from cultured shoot tips, nodal explants and axillary buds which can be used for large-scale multiplication to contribute in alleviating desertification impact on the environment and Humans.
The current study demonstrates that thousands of healthy plantlets of this important forage species A. halimus can be successfully produced within a short period time.

This highly salt-tolerant halophyte could survive at high salinity concentrations, which makes it available for distribution to be cultivated in arid and semi-arid zones of Syria and other neighbouring countries, where a major problem is insufficiency and irregularity of fodder resources. This also can contribute to combat desertification because of its ability to complete its life cycle under very high saline conditions.

\section{References}

Anon (2009): Statistical Year Book, Office of Prime Minister, Central Bureau of Statistics Syria, 493 pp

AL Wasel A (1998): In vitro propagation of Atriplex nummularia L. Arab Universities Journal of Agricultural Sciences. 6: 373-383

Amato G, Stringi L, Gristina L, Meli R \& Accardo A (1990): Propagation by cuttings of Atriplex halimus $\mathrm{L}$. as affected by various rooting factors. In: $6^{\text {th }}$ Meeting FAO on Mediterranean Pastures and Fodder Crops, Bari, Italy, pp 135-137

Araújo S, Silveira J, Almedia T, Rocha I, Morais D \& Viegas R (2006): Salinity tolerance of halophyte Atriplex nummularia L. grown under increasing $\mathrm{NaCl}$ levels. Revista Brasileira de Engenharia Agricolae Ambiental. 10: 848-854

Ashby W \& Beadle N (1975): Salinity factors in the growth of Australian saltbush. Ecology. 38: 344-352

Blumwald E \& Poole R (1986): Kinetics of $\mathrm{Ca}^{2+} / \mathrm{H}^{+}$antiport in isolated tonoplast vesicles from storage tissue of Beta vulgaris. Plant Physiology Rockville. 78: 163-167

Bajji M, Kinet J \& Lutts S (1998): Salt stress effects on roots and leaves of Atriplex halimus L. and their corresponding callus cultures. Plant Science. 137: 131-142

Bajji M, Kinet J, Lutts S \& Almansouri M (2004): Salinity and water stress have contrasting effects on the relationship between growth and cell viability during and after stress exposure in durum wheat callus. Plant Science. 167: 9-18 
Blumwald E, Aharon G \& Apse M (2000): Sodium transport in plant cell. Journal of Biochemistry and Biophysical Methods. 1: 140-151

De Bondt A, Eggermont K, Penninckx I, Goderis I \& Broekaert WF (1996): Agrobacterium-mediated transformation of apple (Malus domestica Borkh): an assessment of factors affecting regeneration of transgenic plants. Plant Cell Reports. 15: 549-554

Flowers T, Troke P \& Yeo A (1977): The mechanism of salt tolerance in halophytes. Annual Review of Plant Physiology 28: 89121

Greenway H, Gunn A \& Thomas DA (1966): Plant response to saline substrate VIII. Regulation of ion concentration in salt sensitive and halophytic species. Australian Journal of Biological Science. 19: 741-756

Harba K (2006): Analyzing the Activities of Combating Desertification in Syria, UNDP, The Ministry of Local Administration and Environment. Damascus, 152 pp

Khan M, Ungar I \& Showalter A (2000): Effects of Salinity on Growth, Water Relations and ion accumulation of the subtropical perennial halophyte Atriplex griffithi var stocksii. Annals Botanic Fennici. 85: 225-232

Khan M \& Duke N (2001): Halophytes a source for the future. Wetland Ecology and Management. 6: 455-456

Khan M, Gul B \& Weber DJ (2001): Effect of salinity on the growth and ion content of Saliconia rubra. European journal of Soil Science. 30: 2965-2977

Khan M, Ungar I \& Showalter A (2005): Salt stimulation and tolerance in an intertidal stem succulent halophyte. Journal of Plant Nutrition. 28: 1365-1374

Kenny L \& Caligari P (1996): Androgenesis of the salt tolerant shrub Atriplex glauca. Plant Cell Reports. 15: 829-832

Korban S, Conner P \& Edobeidy A (1992): Effect of thidiazouron, naphthalenacetic acid, dark incubation and genotype on shoot organogenesis from Malus leaves. Journal of Horticultural Science. 67: 341-349

Kozai T, Ohde N \& Kubota C (1991): Similarity of growth patterns between plantlets and seedlings of Brassica campestris L. Under different in vitro environmental conditions. Plant Cell, Tissue and Organ Culture. 24: 181-186

Kurth E, Cramer G, Launchli A \& Epstien E (1986): Effect of $\mathrm{NaCl}$ and $\mathrm{CaCl}_{2}$ on cell enlargement and cell production in cotton roots. Plant Physiology. 82: 1102-1106

Le Houerou H (1992): The role of saltbush Atriplex spp in arid land rehabilitation in the Mediterranean basin. A review. Agroferstry System. 18: 107-148

Le Houerou H (2000): Utilization of fodder trees and shrubs in the arid and semi arid zones of west Asia and north Africa. Arid Soil Research and Rehabilitation. 14: 101-135

Lutts S, Lefever I, Delperee C, Kivites S, Dechamp C, Ropledo A \& Correal E (2004): Heavy metal accumulation in the halophyte species Mediterranean saltbush. Journal of Environmental Quality. 33: $1271-1250$

Malan J (2000): Selection and propagation of elite Atriplex material.. Biometry and Corp Scienc. 1: 79-89

Mei B, Mcwilliams E, Gould J \& Newton R (1997): In vitro regeneration of fourwing saltbush [Atriplex canescens (Pursh) Nutt]. Journal of Range Management. 50: 413-418
Munns R (2002): Comparative physiology of salt and water stress. Plant Cell and Environment. 25: 239-250

Murai Y, Harada H \& Yanashita H (1997): In vitro propagation of apricot (Prunus armeniaca L.) cv. Bakuoh junkyou. Journal of the Japanese Society for Horticultural Science. 66: 475-480

Murashige T \& Skoog F (1962): A revised medium for rapid growth and bioassays with tobacco tissue cultures. Journal of Plant Physiology. 15: 473-497

Nedjimi B \& Daoud Y (2006): Effect of $\mathrm{Na}_{2} \mathrm{SO}_{4}$ on the growth, water relations, proline, total soluble sugars and ion content of Atriplex halimus subsp. schweinfurthii through in vitro culture. Anales de Biología. 28: 35-43

Nedjimi B, Daoud Y \& Touati M (2006): Growth, water relation, praline and ion content of in vitro cultured Atriplex halimus subsp. schweinfurthii as affected by $\mathrm{CaCl}_{2}$. Communications in Biometry and Crop Science. 1: 79-89

Nitsch JP \& Nitsch C (1969): Haploid plants from pollen grains. Science. 169: 85

Ortíz J, Martinez M, Correal E, Simon B \& Cenis L (2005): Genetic structure of Atriplex halimus population in the Mediterranean basin. Annals of Botany. 95: 827-834

Osmond CB, Bjorkman O \& Anderson DJ (1980): Physiological processes in plant ecology. Berlin, Springer- Verlag. 486 pp

Pierik RLM (1987): In Vitro Culture of Higher Plants, Martinus Nijhoff Publishers, Dordrecht, The Netherlands, 344 pp

Priebe A \& Jäger H (1978): Responses of amino acid metabolizing enzymes from plants differing in salt tolerance to $\mathrm{NaCl}$. Oecologia (Berlin). 36: 307-315

Ramos J, Lopez M \& Benlloch M (2004): Effect of $\mathrm{NaCl}$ and $\mathrm{KCl}$ salt on growth and solute accumulation of the halophyte Atriplex nummularia. Plant and Soil. 259: 163-168

Reddy M, Rao U \& Ungar E (1996): In vitro propagation and related biochemical changes in Atriplex nummularia in saline condition. Journal of Plant Physiology. 1: 10-13

Storey R \& Jones W (1979): Salt stress and comparative physiology in the Gramineae. I. Ion relation of tow salt- and water stressed barley cultivars. California Mariout and Arimar. Australian Journal of Plant Physiology. 5: 801-816

Taiz L \& Zeiger E (1991): Plant Physiology ( $1^{\text {st }}$ edition), The Benjamin Cumming Publishing Co., Los Angeles, 363 pp

Wardeh M (2005): The National Action Plan to Combat Desertification in Syria. The Ministry of Local Administration and Environment. Syria. Damascus, 48 pp

Welander M (1983): In vitro rooting of the apple rootstock M.26 in adult and juvenile growth phases and acclimatization of the plantlets. Journal of Plant Physiology. 58, 231-238

Wilson C, Lesch S \& Grieve C (2000): Growth Stage Modulates Salinity Tolerance of New Zealand Spinach (Tetragonia tetragonioides, Pall.): and Red Orach (Atriplex hortensis L.). Annals of Botany. 85: 501-509

Yepes L \& Aldwinckle M (1994): Factors that effect leaf regeneration efficiency in apple, and effect of antibiotics in morphogenesis. Plant Cell, Tissue and Organ Culture. 37: 257-269

Zohra I, Louiza B \& Moulay B (2008): Influence hormonale sur 1 induction de la collogenes chez Atriplex halimus L et Atriplex Canesens (Pursch. Nutt). European Journal of Scientific Research. 24: $211-218$ 